\title{
THE EFFECT OF CR, DER, AND ROE ON STOCK PRICES TRANSPORTATION SUB SECTOR COMPANIES LISTED ON THE INDONESIA STOCK EXCHANGE
}

\author{
Uswatun Hasanah \\ Faculty of Economics, Universitas Singaperbangsa Karawang, Indonesia \\ 1610631030288@student.unsika.ac.id \\ Hari Sulistiyo \\ Faculty of Economics, Universitas Singaperbangsa Karawang, Indonesia \\ hari.sulistiyo@fe.unsika.ac.id
}

\begin{abstract}
The Effect of CR, DER, and ROE On Stock Prices Transportation Sub Sector Companies Listed On the Indonesia Stock Exchange. This study aims to determine the effect of CR, DER, and ROE on Stock Price. The method used is descriptive statistics with a quantitative approach, namely through the classical assumption test to analyze data and multiple linear regression analysis and data processed using software SPSS 20 . The data used is secondary data with the type of quantitative data. The population of this study is companies sub sector transportation listed on Indonesia Stock Exchange period 2015 until 2018 with a sampling method is purposive sampling, so the number of observation is 11 (eleven) companies. Based on results of this study, it is known that the results of testing together (simultaneous) with the statistical test show that the CR, DER, and ROE affect to the Stock Price at transportation sub sector companies on Indonesia Stock Exchange period 2015-2018. Partially, the CR and DER does not affect to the Stock Price. However, ROE affect to the Stock Price
\end{abstract}

Keywords: CR, DER, ROE, and Stock Price

\begin{abstract}
Abstrak: Pengaruh CR, DER, dan ROE Terhadap Harga Saham Perusahaan Sub Sektor Transportasi Yang Terdaftar Di Bursa Efek Indonesia. Penelitian ini bertujuan untuk mengetahui pengaruh CR, DER, dan ROE terhadap Harga Saham. Metode yang digunakan adalah statistik deskriptif dengan pendekatan kuantitatif, yaitu melalui uji asumsi klasik untuk menganalisis data dan analisis regresi linier berganda dan data diolah menggunakan perangkat lunak SPSS 20. Data yang digunakan adalah data sekunder dengan jenis data kuantitatif. Populasi penelitian ini adalah perusahaan transportasi sub sektor yang terdaftar di Bursa Efek Indonesia periode 2015 hingga 2018 dengan metode pengambilan sampel adalah purposive sampling, sehingga jumlah sampel adalah 11 (sebelas) perusahaan. Berdasarkan hasil penelitian ini, diketahui bahwa hasil pengujian secara bersama-sama (simultan) dengan uji statistik menunjukkan bahwa CR, DER, dan ROE berpengaruh terhadap Harga Saham pada perusahaan sub sektor transportasi di Bursa Efek Indonesia periode 2015-2018. Secara parsial, CR dan DER tidak mempengaruhi Harga Saham. Namun ROE mempengaruhi harga saham.
\end{abstract}

Kata Kunci: CR, DER, ROE, dan Harga Saham.

\section{INTRODUCTION}

In the era of globalization companies are required to generate large profits in order to be able to compete with other companies. So the company must work hard in optimizing and maintaining its business. One alternative for companies can develop by getting additional funds through the capital market. According to Kamus Besar Bahasa Indonesia (KBBI), the notion of the capital market is all activities that bring together supply and demand or are activities that trade securities. 


\section{Nominal: Barometer Riset Akuntansi dan Manajemen}

P-ISSN: 2303-2065 E-ISSN: 2502-5430

Volume 10 No 1 (2021)

In capital market activities, stock prices are the main factor. Stock prices must also be considered by investors before investing their capital. The stock price is a reflection of the success of the company's management in carrying out the company's operations. Stock prices can be volatile. In the stock price there is what is called the IDX Composite. IDX composite is an index that measures the movement of all stock listed on the Indonesia Stock Exchange (IDX). IDX composite is a barometer that shows the ups and downs of joint stock prices on the IDX.

There are several conditions and situations that determine a stock that will experience fluctuations (Fahmi, 2017: 57), including micro and macroeconomic conditions, the company's policy in deciding to expand (business expansion), such as opening a branch office, a good branch office used domestically and abroad. The next is the sudden change of directors, the existence of directors or commissioners of companies involved in criminal acts and cases that have gone to court, company performance continues to decline at any time, systematic risk is a form of risk that occurs as a whole and has participated causing companies to get involved, and the last is the effect of market psychology that was able to suppress the technical conditions of buying and selling stock.
Of the factors that affect stock prices, some can be a factor in the decline in stock prices in one of the transportation subsectors listed on the Indonesia Stock Exchange. If the company has a good performance, it will allow its investors to attract stock. increased stock demand will be able to increase stock prices as well so that it can be an indicator in analyzing the company's financial performance and vice versa.

On average, each company can show stock prices below average and above average. The amount of data that gets results above the average is 20 data from a total of 44 data. And the amount of data that gets results below the average is 24 data from a total of 44 data. This shows that the sample data of stock prices in the transportation subsector company has a low performance.

One decline in stock prices in the transportation subsector companies can also be caused by more and more online transportation companies that have sprung up. In Indonesia, non-online transportation has been used for a long time, but nowadays online transportation that can be easily called via smartphones is growing rapidly. Online transportation is relatively better than nononline transportation. Both in terms of service, convenience and price certainty, which has so far been lacking in non-online transportation. 
Decline in stock prices can also be seen from the ratio owned by the company. The first is Current Ratio (CR). According to Kasmir (2015: 134) that the current ratio $(\mathrm{CR})$ is a ratio to measure the company's ability to pay short-term obligations or debt that will soon mature. In other words, how much current assets are available to cover short-term liabilities that are immediately due.

CR produced by each transportation subsector company has a varying trend. In 2015, NELY was the company with the highest CR of $316.37 \%$. In 2016 the company with the lowest CR was KARW of $7.26 \%$. In 2017, NELY has the same position as in 2015. CR in NELY companies in 2016 amounted to $603.82 \%$. Furthermore, in 2018, KARW again occupied the lowest CR of $10.97 \%$. So it can be concluded that the company that has the highest CR level is NELY, which indicates that NELY companies are very liquid. While the company that has the lowest $\mathrm{CR}$ is KARW this means that the KARW company is unable to pay off its short-term debt because the limit for measuring $\mathrm{CR}$ is $200 \%$, at this point the company already feels safe in paying off its short-term debt.

The next ratio is Debt to Equity Ratio (DER). According to Kasmir (2015: 156) that Debt to Equity Ratio (DER) is a debt ratio that is used to measure the ratio of total debt to total assets. In 2015 the average DER was $1.35 \%$, in 2016 it was $1.01 \%$, in 2017 it was $1.01 \%$, and in 2018 it was $0.96 \%$. The higher the ratio of debt to capital, the better, the best ratio if the amount of capital is greater than the amount of debt or at least the same. If the DER is too high, it shows that the debt composition is greater than the total own capital so that the greater the company's burden on outsiders. It can be concluded that when the DER is high the stock prices will go down and vice versa when the low DER indicates the stock prices rises.

The last ratio is Return On Equity (ROE). According to Kasmir (2015: 204) that Return On Equity (ROE) is a ratio to measure net income after tax with own capital. This ratio shows the efficiency of using their own capital. In 2015 the average ROE was $17.12 \%$, in 2016 it was $7.40 \%$, in 2017 it was $5.84 \%$, and in 2018 it was $5.53 \%$. This ratio shows the efficiency of using their own capital. The higher this ratio, the better. This means that the owner of the company is getting stronger, and vice versa. The decline in ROE is usually followed by a decline in the company's stock price. If the ROE level is high, it will attract investors, because the company is able to generate good income as well.

Based on the results of previous research on each variable, research on the effect of the $\mathrm{CR}$ variable on stock prices conducted by 


\section{Nominal: Barometer Riset Akuntansi dan Manajemen}

P-ISSN: 2303-2065 E-ISSN: 2502-5430

Volume 10 No 1 (2021)

Fitrianingsih \& Budiansyah (2018) found that $\mathrm{CR}$ affects stock prices, while these findings are supported by the results of previous research conducted by Amalya (2018) in the Coal Mining Sector Company that ROE affects stock prices. In addition, the results of research conducted by Graha, Tandika \& Azib (2017) also state that DER has an effect on stock prices.

One of the stock of a type of stock is a conventional stock grouping, namely stock of companies that are conventionally operational. Given the importance of stock valuations for investors to determine whether investors will invest in the company. Based on the background, as well as the financial data above, and previous results, the authors take research with the title "The Effect of $\boldsymbol{C R}$, DER, and ROE On Stock Prices Transportation Sub Sector Companies Listed On The Indonesia Stock Exchange”.

Based on the above problem formulation, the objectives of this study include: To determine the effect of the CR on stock prices in the transportation subsector that is listed on the Indonesia Stock Exchange. To determine the effect of DER on stock prices in the transportation subsector that is listed on the Indonesia Stock Exchange. To determine the effect of ROE on stock prices in the transportation subsector that is listed on the Indonesia Stock Exchange.To determine the effect of the CR, DER, and
ROE on stock prices in the transportation subsector that is listed on the Indonesia Stock Exchange.

\section{LITERATURE REVIEW}

\section{Signaling Theory}

According to Fauziah (2017:11) Signaling theory is one of the pillar theories in understanding financial management. In general, the signal is interpreted as a signal made by the company to investors. these signals can take the form of various forms, both those that can be directly observed and those that must be examined in more depth in order to find out. The signal delivered can be positive and negative signals.

According to Bringham \& Houston (2006: 185) signal theory suggests how a company should give signals to users of financial statements. The signal is one of the actions taken by company management that provides instructions for investors about how management views the company's prospects.

According to Akerlof (1970) based on his research, there is information asymmetry between the seller and the buyer, where the seller has more information than the buyer. To avoid adverse selection, sellers of quality goods provide signals regarding information on the quality of goods being sold so that buyers can access them. 


\section{Nominal: Barometer Riset Akuntansi dan Manajemen}

P-ISSN: 2303-2065 E-ISSN: 2502-5430

Volume 10 No 1 (2021)

According to Spence (1973) in his research states that by providing a signal, management tries to provide relevant information that can be used by investors. Then, the investor will adjust his decision according to his understanding of the signal.

\section{Stock}

According to Djoni \& Elizabeth (2019) in her journal, stocks are one indicator of company management. Success in increasing profits will provide satisfaction for rational investors.

According to Martalena \& Maya (2011) in journal Kundiman \& Hakim (2016), stocks are an investment instrument that many investors choose because shares are able to provide attractive returns.

According to Salim (2010: 5), stocks are a form of capital participation in a company. when owning shares of a company, we can say we own the company by a certain percentage according to the number of shares owned.

According to Fahmi (2017: 184), a stock is a proof that is given as an ownership of capital or funds in a company, or a paper that is clearly listed in nominal value, the name of the company and followed by the rights and obligations described to each holder.

\section{Types of Stocks}

In the capital market there are two types of stocks that are most commonly known by the public, namely common stock and preferred stock. Each share has its own meaning and regulations (Fahmi, 2017: 54):

1. Common Stock

Common stock is a securities sold by a company that explains the nominal value (rupiah, dollar, yen and so on) where the holder is given the right to attend the GMS (General Meeting of Shareholders) and EGMS (Extraordinary General Meeting of Shareholders) and is entitled to determine whether to buy a rights issue (sale of ordinary shares) or not, which in the end of the year will benefit in the form of dividends.

\section{Preferred Stock}

Preferred stock is a securities sold by a company that explains the nominal value (rupiah, dollar, yen and so on) where the shareholders will get fixed income in the form of dividends that will be received every quarter (three months).

\section{Stock Prices}

According to Jogiyanto (2008) in journal Anah, Firdaus, \& Alliffah (2018), the stock price is the price that occurs in the stock market at a certain time determined by the demand and supply concerned in the capital market.

According to Ginting (2013) in journal Kartikasari (2019), a stock price is the selling 
price of a stock from one investor to another that occurs in the capital market.

According to Darmadji and Fakhruddin (2006) in journal Kundiman \& Hakim (2016), stock prices are the value of shares determined by the strength of the share purchase offer in certain market mechanisms and are the selling prices from one investor to another.

\section{Factor Affecting Stock Prices}

According to Fahmi (2017: 57) there are a number of conditions and situations that affect stock price fluctuations, including

1. Micro and macro economic conditions

2. Company policy in deciding to expand (business expansion), such as opening a brand office, sub brand office both opened in domestic and abroad.

3. Sudden change of directors

4. The existence of a board of directors or a company commissioner involved in a crime and the case has gone to court

5. The company's performance continues to decline in every time

6. Systematic risk, which is a form of risk that occurs as a whole and has contributed to causing companies to get involved

7. The effects of market psychology that were able to suppress the technical conditions of buying and selling shares.

\section{Financial Ratio Analysis}

According to Fahmi (2017:107), the ratio is referred to as the ratio of the number, from one amount to another, it is seen that the comparison with the hope that later will be found answers which will then be used as study material to be analyzed and decided.

According to Kasmir (2015: 104), financial ratios are activities that compare the numbers in a financial statement by dividing one number with another number.

According Sujarweni (2018: 109), financial ratios are activities to analyze financial statements by comparing one account with another account in the financial statements, the comparison can be between accounts in the balance sheet and income statement.

\section{Benefits of Financial Ratio Analysis}

Besides having a very important role before making investments, financial ratio analysis also has several benefits including (Fahmi, 2017: 109):

1. Financial ratio analysis is very useful to be used as a tool to assess company performance and achievement.

2. Financial ratio analysis is very useful for management as a reference for planning

3. Financial ratio analysis can be used as a tool to evaluate a company's condition from a financial perspective. 


\section{Nominal: Barometer Riset Akuntansi dan Manajemen}

P-ISSN: 2303-2065 E-ISSN: 2502-5430

Volume 10 No 1 (2021)

4. Financial ratio analysis is also useful for creditors which can be used to estimate what risks will be faced associated with the existence of guaranteed continuity of interest payments and repayment of loan principal.

5. Analysis of financial statements can be used as an appraisal of the stakeholders of the organization.

In analyzing stock prices, financial ratio analysis is very necessary, according to Kasmir (2015: 106) forms of financial ratios:

1. Liquidity ratio

2. Solvency ratio (Leverage Ratio)

3. Activity ratio

4. Profitability ratio

5. Growth ratio

6. Rating ratio

In this study the ratio used to measure the company's stock price is the liquidity ratio (CR), the ratio of solvency or leverage (DER) and the profitability ratio (ROE). The following is an explanation of these ratios:

\section{Current Ratio}

According to Kasmir (2015: 134), Current Ratio is a ratio to measure a company's ability to pay short-term obligations or debt that will mature when it is billed as a whole.

According to Fahmi (2017: 121), current ratio is a measure commonly used for short- term solutions, the ability of a company to meet debt needs when due.

According to Sugiono \& Untung (2016: 58), the Current ratio is used to determine the extent to which the company's current assets are used to pay off current liabilities (liabilities) that will be due or paid immediately.

The formula for finding the current ratio can be used as follows.

$$
\text { Current Ratio }=\frac{\text { Current Assets }}{\text { Current Liabilities }}
$$

Source : Kasmir (2015:135)

\section{Debt to Equity Ratio}

According to Kasmir (2015: 157), Debt to Equity Ratio is a ratio used to assess debt with equity. This ratio is sought by comparing all debt, including current debt and all equity.

According to Ikatan Bankir Indonesia (2015: 63), Debt to equity ratio shows how far creditors are protected by shareholder investments, meaning how much the value of assets can decrease before the creditor suffers a loss. This ratio illustrates the risk of shareholders compared to the risk of creditors.

According to Rangkuti (2011: 184), Debt to equity ratio is a comparison between total liabilities (total debt) with total own capital (equity). This ratio shows the extent to which 
equity capital guarantees all debt. This ratio can also be read as a comparison between outside parties and company owner funds entered into the company.

The formula to find the debt to equity ratio can be used as a comparison between total debt and total equity as follows.

$$
\text { Debt to Equity Ratio }=\frac{\text { Total Utang }}{\text { Ekuitas }}
$$

Source : Kasmir (2015:158)

\section{Return On Equity}

According to Kasmir (2015: 204), Return on equity is a ratio to measure net income after tax with own capital. This ratio shows the efficiency of using their own capital. The higher this ratio, the better. This means that the position of the owner of the company is getting stronger, and vice versa.

According to Fahmi (2017: 137), return on equity examines the extent to which a company uses its resources to be able to provide a return on equity.

According to Ikatan Bankir Indonesia (2015: 65), return on equity provides an illustration of how efficient a company is in using equity to generate profits.

The formula for finding return on equity can be used as follows.

$$
(R O E)=\frac{\text { Earning After Interest and Tax }}{\text { Equity }}
$$

Source : Kasmir (2015:204)

\section{Conceptual Framework}

\section{The Effect of Current Ratio $\left(X_{1}\right)$ to Stock Prices (Y)}

Liquidity ratio is a ratio that measures the value of a company's ability to meet its shortterm obligations according to a predetermined due date. In this study the ratio used is the current ratio, arguing that the current ratio can show the company's ability to meet its short-term debt. The higher the level of the current ratio will have a positive impact on the company because it will attract investors to invest in the company, by attracting a lot of investor interest, it will also have a good impact on stock prices. The stock price of the company will increase according to the number of investors who invest their capital. Vice versa if the company has a low value on the current ratio it will have a negative impact on the company, this is because current assets are not able to cover the company's debt. With a low current ratio value, it will not attract investors to invest their capital. Based on this description it can be concluded that the current ratio has a positive effect on stock prices.

\section{The Effect of Debt to Equity Ratio $\left(\mathbf{X}_{2}\right)$ to Stock Prices (Y)}

Leverage ratio is a ratio that measures how much the company's assets are financed by debt, if the company's debt is greater than the assets it will have a negative impact on 


\section{Nominal: Barometer Riset Akuntansi dan Manajemen}

P-ISSN: 2303-2065 E-ISSN: 2502-5430

Volume 10 No 1 (2021)

the company. In this study, the variable used is the debt to equity ratio, arguing that the debt to equity ratio can be known how much the company is financed by debt, then how much the company's burden can meet the debt provided by creditors. If the company's operations are largely costed by debt, it will have a negative impact, because profits earned by the company will be prioritized to pay the company's obligations first. Large debt will be a burden on the company and in terms of investment will reduce the interest of investors to invest their capital. Declining investor interest will have an impact on the company's stock price.

\section{The Effect of Return On Equity $\left(\mathrm{X}_{3}\right)$ to Stock Prices (Y)}

Profitability ratio is a ratio that measures the amount of profit gained by a company related to sales or investment. In this study the ratio used is return on equity, with the reason how much the company's ability to generate profits that come from their own capital. If the company is able to generate profits with its own capital it will have a positive impact on the company, because with high profits will increase demand for shares and the company's stock price will increase. High return on equity shows that the company generates high profits with its own capital and does not use funds from external parties such as creditors, high profitability proves that the company has large internal funds and capital so as to produce high profits. Based on the description, it can be concluded if the return on equity affects the stock price.

\section{Conceptual Framework}

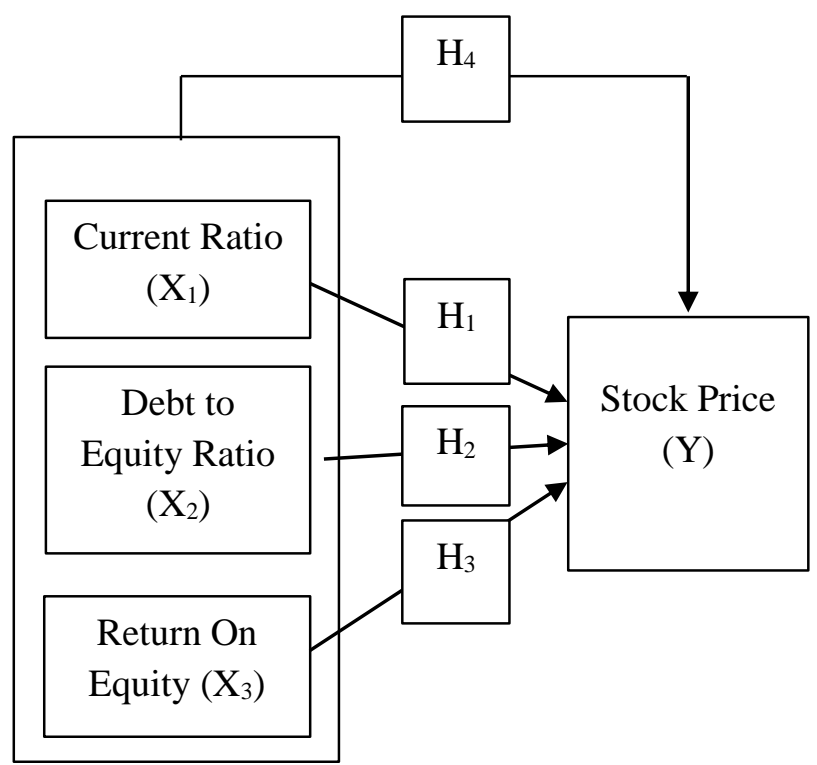

Figure 1: Conceptual Framework

H1: Current Ratio (CR) is affect the stock price of the Transportation Subsector companies listed on the Indonesia Stock Exchange for the period of 2015-2018.

H2: Return On Equity (ROE) is affect the stock price of the Transportation Subsector companies listed on the Indonesia Stock Exchange for the period of 2015-2018.

H3: Debt to Equity Ratio (DER) is affect the stock price of the Transportation Subsector Companies listed on the Indonesia Stock Exchange Period 20152018. 
H4: Current Ratio (CR), Return On Equity (ROE), and Debt to Equity Ratio is affect the stock price of the Transportation Subsector companies listed on the Indonesia Stock Exchange Period 20152018.

\section{RESEARCH METHODOLOGY}

\section{Type of Research}

This sudy uses a descriptive verification research type with a quantitative approach that is associated with problems that exist in the object of research regarding the effect of public accounting firm reputation, audit opinion and auditor switching on audit delay.

\section{Place and Time Research}

The data source used in this study is secondary data, which is gathered by a secondary party. The data used was obtained through the internet site www.idx.co.id and www.sahamok.com. This research was conducted in February 2020 until July 2020.

\section{Research Subject}

Population is a generalization area consisting of: objects / subjects that have certain quantities and characteristics determined by researchers to be studied and then drawn conclusions (Sugiyono, 2013: 148).

Based on this understanding, the population is a generalization area consisting of obyek or subjects that have certain quantities and characteristics to study and draw conclusions, the population used in this study is the transportation subsector companies that was listed on the Indonesia Stock Exchange in 2015-2018.

In the selection of samples in this study, researchers used purposive sampling, where in this purposive sampling researchers had criteria and objectives for the sample to be studied. Purposive sampling is a sampling technique with certain considerations (Sugiyono, 2017: 85).

Based on this research the sample used is the transportation subsector companies listed on the Indonesia Stock Exchange with 4 (four) years financial statements during the 2015-2018 period.

\section{Data Analysis Technique}

The analysis technique in this research is multiple linear regression analysis, partially test ( $\mathrm{t}$ test), simultaneously test ( $\mathrm{F}$ test), and determinant coefficient test $\left(\mathrm{R}^{2}\right)$.

\section{RESULTS AND DISCUSSION}

\section{Results}

\section{Descriptive Statistic Analysis}

This research the sample used is the transportation subsector companies listed on the Indonesia Stock Exchange with the total sample is 11 (eleven) companies. 
Table 1: Result of Descriptive Statictic by Variable data

\begin{tabular}{lcccc}
\hline Description & Y & X1 & X2 & X3 \\
\hline Min & 50 & 7.26 & - & - \\
Max & 1950 & 316.37 & 3.71 & 42.60 \\
Mean & 483.26 & 91.02 & 1.17 & 6.82 \\
SD & 467.21 & 66.52 & 1.21 & 18.79 \\
\hline
\end{tabular}

Based on descriptive statistic it can be seen that CR shows the standard deviation is smaller than the average value, meaning that in this study the data is normally distributed. While the min CR value is 7.26 and the max value is 316.37 .

Based on descriptive statistic it can be seen that DER shows the standard deviation is greater than the average value, meaning that in this study the data is not normally distributed. While the min DER value is 2.07 and the max value is 3.71 .

Based on descriptive statistic it can be seen that ROE shows the standard deviation is greater than the average value, meaning that in this study the data is not normally distributed. While the min ROE value is 42.60 and the max value is $\mathbf{5 2 . 5 7}$

Based on descriptive statistic it can be seen that stock price shows the standard deviation is smaller than the average value, meaning that in this study the data is normally distributed. While the value of the min stock price is 50 and the max value is 1950.

\section{Test Data Normality}

Testing for normality uses the Kolmogorov-Smirnov test shown in table 2.

Table 2. Normality Test Before Outlier

\begin{tabular}{lccc}
\hline Variable & $\begin{array}{c}\text { Significan } \\
\mathbf{t}\end{array}$ & $\begin{array}{c}\text { Asymp. } \\
\text { Sig. }\end{array}$ & $\begin{array}{c}\text { Descriptio } \\
\mathbf{n}\end{array}$ \\
\hline Unstandard & 0,05 & 0,000 & Not normal \\
ized & & & \\
residual & & & \\
\hline
\end{tabular}

Based on the results of the normality test using Kolmogorov Smirnov it is known that the data in this study are not normally distributed. The way to overcome data abnormalities is by outliers by removing data that has extreme values.

\section{Normality test results after outlier}

Based on the test results above, obtained a residual value of 0.132 so that $0.132>0.05$ so that it can be said that the data used in the study were normally distributed

Table 3. Normality Test After Outlier

\begin{tabular}{llll}
\hline Variable & Sig. & $\begin{array}{l}\text { Asymp. } \\
\text { Sig. }\end{array}$ & $\begin{array}{l}\text { Descrip } \\
\text { tion }\end{array}$ \\
\hline $\begin{array}{l}\text { Unstandardize } \\
\text { d residual }\end{array}$ & 0,05 & 0,132 & Normal \\
\hline
\end{tabular}

\section{Multicollinearity Test}

Based on the multicollinearity test results on table 4, that the VIF value of CR 1,087, DER 1,073, and ROE 1,136 are between values 1 through 10 . Thus, it can be concluded that the data is free from the multicollinearity test. 
Tabel 4. Results of Multicollinearty Test

\begin{tabular}{lll}
\hline Variable & Tolerance & VIF \\
\hline CR & 0,920 & 1,087 \\
DER & 0,932 & 1,073 \\
ROE & 0,880 & 1,136 \\
\hline
\end{tabular}

\section{Heteroscedasticity Test}

Based on the test results on figure 2 obtained images that have points that have unclear patterns and these points are below and above the number 0 , it can be concluded that the multiple linear regression analysis in this study is free from symptoms of heteroscedasticity.

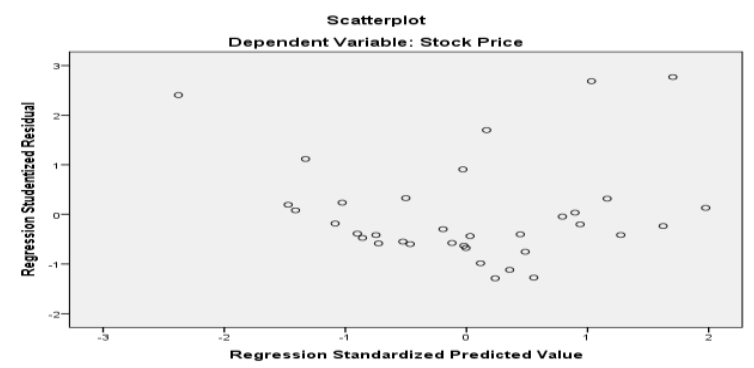

Figure 2: Heteroscedasticity Test

\section{Autocorrelation Test}

Based on the above test, a D-W value of 0.902 is obtained (see table 5). This means that the D-W value of 0.902 is still between 2 and +2 . Thus it can be concluded that the regression analysis in this study is free from autocorrelation symptoms.

Table 5. Results of Autocorellation Test

\begin{tabular}{rccccc}
\hline Model & $\mathbf{R}$ & $\mathbf{R}^{2}$ & $\begin{array}{c}\text { Adjusted } \\
\mathbf{R}^{\mathbf{2}}\end{array}$ & SEE & D-W \\
\hline 1 & $.656^{\mathrm{a}}$ & 0.431 & 0.375 & 369.223 & 0.902 \\
\hline
\end{tabular}

\section{Goodnes of Fits Test}

Determinant Coefficient Test $\left(\mathbf{R}^{\mathbf{2}}\right)$
From the results drpict in table 6, it can be seen that the coefficient of determination (R2) is 0.431 or $43.1 \%$. This shows that the variables studied are CR, DER, and ROE affect $43.1 \%$ of the Stock Price. While the remaining $56.9 \%$ is influenced by variables not examined in this study or confounding variables.

Table 6. Result of Determinant Coefficient

\begin{tabular}{ccccc}
\hline Model & $\mathbf{R}$ & $\mathbf{R}^{2}$ & \multicolumn{1}{c}{ Adjusted $\mathbf{R}^{\mathbf{2}}$} & SEE \\
\hline 1 & 0,656 & 0,431 & 0,375 & 369,223 \\
\hline
\end{tabular}

\section{Partially Test (t test)}

Table 7. Result of t test CR on Stock Price

\begin{tabular}{llll}
\hline $\begin{array}{l}\text { Independent } \\
\text { Variable }\end{array}$ & $\begin{array}{l}\text { Dependent } \\
\text { Variable }\end{array}$ & tcount & Sig. \\
\hline $\mathrm{CR}(\mathrm{X} 1)$ & Stock Price (Y) & $-0,816$ & 0,421 \\
\hline
\end{tabular}

Based on the above test, $\mathrm{H} 1$ is rejected because the $t_{\text {count }}$ is -0.816 and the $t_{\text {table }}$ is 2.037 with a significance value of 0.421 , which means it is greater than 0.05 . It means that there is a partial effect between CR on the stock price of the transportation sub sector companies.

Table 8. Result of $t$ test DER on Stock Price

\begin{tabular}{lllll}
\hline $\begin{array}{l}\text { Independent } \\
\text { Variable }\end{array}$ & \multicolumn{2}{l}{$\begin{array}{l}\text { Dependent } \\
\text { Variable }\end{array}$} & $\mathbf{t}_{\text {count }}$ & Sig. \\
\hline DER (X2) & $\begin{array}{l}\text { Stock Price } \\
\text { (Y) }\end{array}$ & 1.167 & 0,252 \\
& & & \\
\hline
\end{tabular}

Based on the above test, $\mathrm{H} 2$ is rejected because the $t_{\text {count }}$ is 1.167 and the $t_{\text {table }}$ is 2.037 with a significance value of 0.252 , which means it is greater than 0.05 . It means that there is a partial effect between DER on the stock price of the transportation sub sector companies. 
Nominal: Barometer Riset Akuntansi dan Manajemen

P-ISSN: 2303-2065 E-ISSN: 2502-5430

Volume 10 No 1 (2021)

Table 9. Result of t test ROE on Stock Price

\begin{tabular}{llll}
\hline $\begin{array}{l}\text { Independent } \\
\text { Variable }\end{array}$ & $\begin{array}{l}\text { Dependent } \\
\text { Variable }\end{array}$ & $\mathbf{t}_{\text {count }}$ & Sig. \\
\hline ROE $(\mathrm{X} 3)$ & $\begin{array}{l}\text { Stock Price } \\
\text { (Y) }\end{array}$ & 4.291 & 0,000 \\
& & & \\
\hline
\end{tabular}

Based on the above test, H3 is accepted because the $t_{\text {count }}$ is 4.291 and the $t_{\text {table }}$ is 2.037 with a significance value of 0.000 , which means it is smaller than 0.05 . It means that there is a partial effect between ROE on the stock price of the transportation sub sector companies.

\section{Simultaneously Test (F Test)}

Based on the above test, $\mathrm{H} 4$ is accepted because the Fcount is 7.814 and the ttable is 2.911 with a significance value of 0.001 , which means it is smaller than 0.05. This means that there is a simultaneous effect between CR, DER, and ROE on the stock price of the transportation sub sector companies.

Table 10. Result of F Test

\begin{tabular}{llll}
\hline $\begin{array}{l}\text { Independent } \\
\text { Variable }\end{array}$ & $\begin{array}{l}\text { Dependent } \\
\text { Variable }\end{array}$ & F $_{\text {count }}$ & Sig. \\
\hline CR (X1) & Stock Price (Y) & 7,814 & 0,001 \\
DER (X2) & & \\
ROE (X3) & & \\
\hline
\end{tabular}

\section{Discussion}

The company's current ratio does not affect the stock price. High or low CR is not a factor that influences investors to invest their capital. Within the transportation subsector company, on average, CR levels are quite high. So the company's ability to pay the short-term obligations can be said to be good and has no influence on the ups and downs of the stock price. This research is supported by the results of research conducted by Nur'aidawati (2018) which states that the $\mathrm{CR}$ value has no impact on the company's stock price.

The debt to equity ratio owned by the company does not affect the stock price. High and low DER is not a factor that influences investors to invest their capital. Within the transportation subsector, the average company has a fairly low DER level. So the company's ability to pay the long-term obligations can be said to be quite good and has no influence on the ups and downs of the stock price. This research is supported by the results of research conducted by Amalya (2018) which states that investors do not support the company's ability to use capital with debt.

The return on equity owned by a company can affect the stock price. ROE is a signal for investors, high and low levels of ROE are factors that influence investors to invest their capital. So this can indicate that investors are interested in getting long profits in the form of dividends. This research is supported by the results of research conducted by Kristanti \& Sutono (2016) which states that any increase in ROE will follow an increase in the value of stock prices. 
Based on the research results, the Current Ratio, Debt to Equity Ratio, and Return on Equity simultaneously affect the Stock Price of the transportation sub-sector company on the Indonesia Stock Exchange 2015-2018 Period. This ratio is seen more from the point of view of the company's profitability. good profit makes investors give consideration to placing their funds in a company so that it will also affect the stock price.

\section{CONCLUSIONS AND SUGGESTIONS}

\section{Conclusion}

This study examines the effect of CR, DER, ROE on stock prices in the transportation subsector companies listed on the Indonesia Stock Exchange period 20152018. Based on the results of research and discussion that has been described, the following conclusions can be drawn:

1. CR ha no effect on stock price in the transportation subsector companies listed on the Indonesia Stock Exchange for the 2015-2018 period.

2. DER has no effect on stock prices in the transportation subsector companies listed on the Indonesia Stock Exchange in the 2015-2018 period.

3. ROE has an effect on stock prices in the transportation subsector companies listed on the Indonesia Stock Exchange in the 2015-2018 period.
4. CR, DER and ROE affect the stock price in the transportation subsector companies listed on the Indonesia Stock Exchange in the 2015-2018 period.

\section{Suggestions}

Based on the conclusions in this study, the authors provide the following suggestions:

1. The government also expected to provide education and socialization about the capital market to various groups because there is still a lack of public knowledge about the capital market.

2. As capital market players, investors also need to pay attention to the implications of the integration of the capital market will certainly affect investment prospects for domestic and in integrated countries.

3. For academics and further research, the results of this study are expected to be used as a reference material and are expected to further analyze the indicators of capital market integration by using monthly data in this case the closing price of the stock index. The next researcher is expected to be able to add other factors that can influence the integration of the capital market, for example with economic factors, currency, geographical location and others.

4. For the public, with the results of this study it is expected that the public will 
participate more in the capital market.

This was done so that the capital market in Indonesia could continue to grow and be able to compete with other countries.

\section{REFERENCE}

Akerlof, G. A., 1970, "The Market for "Lemons": Quality Uncertainty and the Market Mechanism", The Quarterly Journal of Economics, 84 (3): 488-500.

Anah, S., Firdaus, I., \& Alliffah, E. (2018). Pengaruh Current Ratio, Debt to Equity Ratio, dan Price Book Value Terhadap Harga Saham Pada Sub Sektor Transportasi yang Terdaftar di BEI Periode 2012-2016. Jurnal Ekonomi, 403-416.

Amalya, N. T. (2018). Pengaruh Return On Asset, Return On Equity, Net Profit Margin dan Debt to Equity Ratio terhadap Harga Saham. Jurnal Sekuritas, 157-181.

Bringham, \& Houston. (2006). Dasar-Dasar Manajemen Keuangan. Jakarta: Salemba Empat.

Djoni, R. J., \& Elizabeth, S. M. (2019). Pengaruh Return On Asset (ROA), Debt to Equity Ratio (DER), Current Ratio (CR), dan Ukuran Perusahaan Terhadap Harga Saham Perusahaan Sektor Keuangan yang Terdaftar di Singapore Exchange (SGX) Periode 2014-2017. STIE Multi Data Palembang .

Fahmi, I. (2017). Analisis Laporan Keuangan. Bandung: Alfabeta.

Fauziah, F. (2017). Kesehatan Bank, Kebijakan Dividen, dan Nilai
Perusahaan. Samarinda: RV Pustaka Horizon.

Fitrianingsih, D., \& Budiansyah, Y. (2018). Pengaruh Current Ratio Dan Debt To Equity Ratio Terhadap Harga Saham Di Perusahaan Food And Beverage Yang Terdaftar Di Bursa Efek Indonesia Periode 2013-2017. Jurnal Riset Akuntansi Terpadu, 144-166.

Graha, R. B., Tandika, D., \& Azib. (2017). Pengaruh Debt to Equity Ratio dan Earning Per Share terhadap Harga Saham Studi Kasus pada Perusahaan Subsektor Logam dan Mineral yang Terdaftar di BEI. Prosiding Manajemen.

Ikatan Bankir Indonesia. (2015). Manajemen Risiko 2. Jakarta (ID): Gramedia.

Kartikasari, U. (2019). Pengaruh Debt to Equity Ratio,Current Ratio dan Return On Asset Terhadap Harga Saham Perusahaan Infrastruktur Terdaftar di Bursa Efek Indonesia Periode 2008-2017. Manners.

Kasmir. (2015). Analisis Laporan Keuangan. Jakarta: PT RajaGrafindo Persada.

Kristanti, N., \& Sutono. (2016). Pengaruh Earning Per Share, Return On Equity, dan Debt to Equity Ratio Terhadap Harga Saham pada Perusahaan Food and Beverage yang Terdaftar di Bursa Efek Indonesia . Dharma Ekonomi.

Kundiman, A., \& Hakim, L. (2016). Pengaruh Current Ratio, Deb to Equity Ratio, Return On Asset, Return On Equity Terhadap Harga Saham Pada Indeks LQ 45 di BEI Periode 2010-2014. Among Makarti.

Nur'aidawati, S. (2018). Pengaruh Current Ratio (CR), Total Asset Turnover (TATO), Debt to Equity Ratio (DER) 
Nominal: Barometer Riset Akuntansi dan Manajemen

P-ISSN: 2303-2065 E-ISSN: 2502-5430

Volume 10 No 1 (2021)

dan Return On Asset (ROA)

Terhadap Harga Saham dan

Dampaknya Nilai Perusahaan (Studi

Kasus pada Sepuluh Bank Terbesar yang Terdaftar di BEI tahun 20112015). Jurnal Sekuritas, 70-83.

Rangkuti, F. (2011). SWOT Balanced Scorecard. Jakarta: Gramedia.

Salim, J. (2010). Cara Gampang Bermain Saham. Jakarta: Visimedia.

Spence, Michael. 1973. Job Market Signaling. The Quarterly Journal of Economics, Vol. 87, No. 3. (Aug., 1973), pp. 355-374.

Sugiono, A., \& Untung, E. (2016). Analisa Laporan Keuangan. Jakarta: Gramedia.

Sugiyono. (2017). Metode Penelitian Kuantitatif, Kualitatif, dan $R \& D$. Bandung: Alfabeta.

Sugiyono. (2013). Metode Penelitian Manajemen. Bandung: Alfabeta.

Sujarweni, V. W. (2018). Manajemen Keuangan. Yogyakarta: Pustaka Baru Press. 